\title{
Sivilstand og mental helse
}

\author{
Bjørn Lau ${ }^{1}$, Torbjørn Moum ${ }^{1}$, Tom Sørensen ${ }^{2}$ og Kristian Tambs ${ }^{3}$ \\ ${ }^{1}$ Institutt for medisinske atferdsfag, Universitetet i Oslo \\ ${ }^{2}$ Instituttgruppe for psykiatri, Universitetet i Oslo \\ ${ }^{3}$ Nasjonalt folkehelseinstitutt, Oslo
}

\begin{abstract}
SAMMENDRAG
Målet med denne studien var å undersøke sammenhengen mellom mental helse og sivilstand. Med bakgrunn i data fra 37418 personer som deltok i Helseundersøkelsen i Nord-Trøndelag (HUNT), fant vi støtte for at både gifte og samboende kvinner og menn hadde foerre symptomer på angst og depresjon, samt fcerre episoder med alvorlig depresjon i løpet av livet enn enslige og tidligere gifte. Den gunstigere situasjonen blant gifte og samboende når det gjelder nåvcerende symptomer på angst og depresjon kunne i stor grad knyttes til mellomliggende variabler som (a) en bedre økonomisk situasjon, (b) en opplevelse av å ha nok venner, (c) en bedre integrasjon i lokalsamfunnet, og (d) et bedre selvbilde. Den lavere forekomsten av episoder med alvorlig depresjon tidligere i livet kunne ikke knyttes til de nevnte mellomliggende variablene, men kan muligens skyldes forhold rundt (a) selve oppløsningen av tidligere ekteskap/samboerskap, eller (b) tidligere livspåkjenninger knyttet til tilværelsen som enslig. En hypotese om at det å finne seg en partner påvirker menns og kvinners mentale helse fant støtte i prospektive data fra den samme populasjonen. Spørreskjemadata fra 2176 kvinner og menn som var fulgt over en 10-års periode viste at personer som hadde forandret sivilstand fra enslig til gift/ samboende hadde hatt en nedgang i nivået på angst og depresjon. En tilsvarende oppfølging av 385 personer som i 10-års perioden hadde et oppløst ekteskap bak seg viste en tendens til at de som hadde giftet seg på ny eller funnet seg en samboer hadde et lavere nivå av symptomer på angst og depresjon. Men disse sistnevnte resultatene var ikke signifikante, muligens på grunn av det beskjedne antallet $i$ denne gruppen som gjorde at vi ikke hadde tilstrekkelig statistisk styrke til å etablere slike forskjeller sikkert.
\end{abstract}

\section{Lau B, Moum T, Sørensen T, Tambs K. Marital status and mental health. Nor J Epidemiol 2002; 12 (3): 281-290.}

\section{ENGLISH SUMMARY}

The objective of this study was to investigate the relationship between marital status and mental health. Using data from 37,418 individuals participating in the Nord-Trøndelag Health Survey (HUNT), we found support for the idea that married and cohabitating women and men report fewer symptoms of current anxiety and depression as well as fewer episodes of major depression over the lifetime. The more favourable situation among married and cohabitating persons with respect to current symptoms of anxiety and depression to a large extent could be attributed to such intervening variables as (a) a better financial situation, (b) a feeling of having enough friends, (c) a feeling of being integrated in the local community, and (d) better self-esteem. The lower rates of lifetime prevalence of major depression among married and cohabitating individuals could not be tied to the above-mentioned intervening variables, however. It is possible that the elevated rates of major depression among the divorced and separated could be due to circumstances related to (a) the process of breaking up a previous marriage/partnership, or (b) the stresses of strains of being single for an extended period of time. We also found support for our hypothesis that finding a partner would improve mental health among individuals who were single at baseline. Questionnaire responses from 2,176 women and men from the same population who had been followed up over 10 years showed that persons who had changed their marital status from being single to being married/cohabitating reported a decrease in their symptom level for anxiety and depression. A parallel follow-up of 385 persons who during this 10-year period had experienced a divorce showed a trend toward less anxiety and depression among those who had subsequently remarried or found a new partner. However, these latter results were not statistically significant, most probably due to the small group investigated and the concomitant lack of statistical power.

\section{SIVILSTAND OG MENTAL HELSE}

En grunnantakelse i sosialpsykiatrisk forskning er at nære interpersonlige relasjoner og sosial støtte er gunstige for den mentale helsa (Sørensen et al., 2002).
Dersom vi finner bedre mental helse hos personer med mange venner og store/gode sosiale nettverk er det imidlertid ikke gitt at de personlige relasjonene faktisk er årsaksfaktoren. Muligens har personer som i utgangspunktet har god mental helse lettere for å finne 
venner og tiltrekke seg et omfattende sosialt nettverk. Det kan med andre ord tenkes at god mental helse er årsak og ikke virkning i denne sammenheng. Tilsvarende resonnementer gjelder dersom vi ser på betydningen av å ha en ektefelle eller partner: kan det tenkes vi observerer bedre mental helse hos personer i faste parforhold fordi personer med god mental helse har 1) klart å tiltrekke seg og/eller 2) holde på en partner? Dersom vi finner dårlig mental helse spesielt hos personer med oppløste ekteskap/samboerskap bak seg må vi også spørre om det er selve oppløsningen av parforholdet snarere enn mangelen på en partner som har negative konsekvenser. Slike spørsmål viser hvor innfløkte antakelser om etiologi kan være innenfor sosialpsykiatrisk forskning. Både antatte årsaksforhold og selve sykeligheten (sykdomsbildet) utspiller seg som atferd, og de ulike atferdstrekkene og -tilbøyelighetene kan hekte seg på hverandre i kompliserte kjeder av gjensidig samspill.

Når det gjelder sammenhengen mellom mental helse og sivilstand hersker det fremdeles en viss uenighet om hva som er de gjeldende empiriske mønstrene: er det faktisk slik at vi finner bedre mental helse hos gifte og samboende eller er forskjeller i mental helse etter sivilstand i dagens samfunn ubetydelige? Denne artikkelen vil ta for seg begge de nevnte problemstillingene. Først vil vi spørre om vi faktisk finner bedre mental helse blant personer i faste parforhold. Gitt at svaret på dette spørsmålet er bekreftende vil vi lete etter rimelige forklaringer (underliggende mekanismer) på denne sammenhengen. Skyldes den seleksjon inn i og ut av ekteskap/samboerskap ut fra foregående mental helse eller kan vi peke på plausible mellomliggende variabler som kan gjøre rede for sammenhengen mellom ekteskap/samboerskap og mental helse?

I de aller fleste studier som har sett på sammenhengen mellom sivilstand og mental helse har man funnet at personer som lever i ekteskap (eller sammen med en fast partner) har bedre mental helse enn personer som lever alene. Forskjellen er størst når man sammenligner gifte med skilte, enker og enkemenn (Williams et al., 1992; Umberson \& Williams, 1999), hvor de sistnevnte gruppene har høyere nivå av depresjon og pyskiske vansker ("psychological distress") enn gifte (Gove \& Shin, 1989; Umberson et al., 1992; Williams et al., 1992). En mulig grunn til at gifte personer har bedre mental helse enn tidligere gifte kan være at et liv som enslig er preget av vedvarende belastninger slik som økonomiske problemer, og sosial isolasjon som på sin side gir vedvarende psykologisk stress (Mastekaasa, 1994; Menaghan \& Lieberman, 1986; Pearlin \& Johnson, 1977; Umberson \& Williams, 1999).

Det kan se ut til at studier av gjengifte støtter en slik forklaring da personer som har giftet seg på nytt rapporterer høyere nivå av psykologisk velvære enn skilte (Shapiro, 1996; Weingarten, 1985). Weingarten mener at det å gifte seg igjen bidrar til at den negative effekten av skilsmisse på den mentale helsa minsker.
Men to longitudinelle studier viser at gjengifte ikke har en slik positiv effekt. I stedet ser det ut til at skilte, uansett om de gifter seg på nytt, opplever en forbedring $\mathrm{i}$ sitt velvære to til fire år etter skilmissen slik at de kommer på nivå med de som er gifte (Spanier \& Furstenberg, 1982; Booth \& Amato, 1991). Spanier og Furstenberg (1982) mener at grunnen til at man i tverrsnittsundersøkelser finner forskjeller i mental helse mellom skilte og personer som har giftet seg på nytt kan være at det er gått lenger tid siden de gjengiftede skilte seg enn det er siden de som fremdeles er skilte gjorde det.

Når man sammenligner den mentale helsa hos gifte og de som aldri har vært gift, spriker resultatene en del. Etter å ha analysert en rekke indikatorer på mental helse fra "the Epidemiologic Catchment Area study", konkluderte Williams et al. (1992) med at gifte ikke hadde bedre mental helse enn "aldri gifte." I en longitudinell studie hvor unge nygiftes mentale helse ble sammenlignet med "aldri giftes" mentale helse fant heller ikke Horwitz og White (1991) at de gifte hadde bedre mental helse. På den annen side har andre funnet at personer som aldri har vært gift har dårligere mental helse enn de gifte. For eksempel viste en senere oppfølging av studien til Horwitz og White at de som giftet seg og forble gifte hadde et høyere nivå av velvære enn de som forble enslige (Horwitz et al., 1996).

Den positive effekten av å leve med en partner har i stort monn blitt forklart ut fra ressurser som er positivt relatert til mental helse og som gifte personer har mer av enn ikke gifte. Således er økonomiske ressurser, som henger sammen med god mental helse (Kessler, 1982; Ross \& Huber, 1985), noe som gifte personer har mer av enn ugifte, først og fremst gjennom de besparelsene en felles husholdning gir (Ross et al. 1990; Zick \& Smith, 1991). Sosial integrasjon og sosial støtte er også positivt korrelert med god mental helse (Sørensen et al., 2002), og gifte opplever mer av dette enn ugifte (Sørensen et al., 2001). Ved å kontrollere for sosial tilknytning og sosial støtte fant Ross (1995) at forskjellene i mental helse mellom gifte og aldri gifte ble "ikke signifikant". Det ser også ut til at gifte har flere psykologiske ressurser enn aldri gifte i form av bedre selvbilde (Demo \& Acock, 1996; Newcomb, 1987). Positivt selvbilde er også korrelert med god mental helse og kan derfor være en ytterligere grunn til at vi kan finne bedre mental helse hos gifte og samboende enn hos enslige.

I statistisk terminologi er forklaringer som postulerer at gifte oppnår bedre mental helse gjennom de nevnte økonomiske, sosiale og psykologiske faktorene egentlig hypoteser om "mellomliggende variabler", dvs. mekanismer som knytter sivilstand (uavhengig variabel) og mental helse (avhengig variabel) til hverandre $i$ en kausalsekvens.

Med den stadig større utbredelsen av samboerskap blir det svært problematisk å sammenlikne enslige bare med personer som lever i formaliserte/legale ekteskap. Mye kan tyde på at fordelene ved et samliv er like 
store hos personer som lever som samboere som hos regulære ektefeller (se for eksempel Ross, 1995). Det er likevel mulig at formaliserte ekteskap er preget av større stabilitet og gjensidig forpliktelse enn samboerskap. I det følgende vil vi derfor skille empirisk mellom personer som lever i formaliserte ekteskap (slik som det fremgår av offentlige registre) og samboere (oppgitt ved selvrapport i spørreskjemaet).

Dårlig mental helse hos enslige kan presumptivt knyttes til omstendigheter rundt den nåværende livssituasjon, slik som skissert ovenfor i avsnittet om "mellomliggende variabler". Den spesielt utsatte situasjonen som man ofte finner hos tidligere gifte/samboende har blitt knyttet til forhold rundt selve oppløsningen av parforholdet (Umberson \& Williams, 1999) og skulle derfor være mer utpreget for mål på mental helse som dekker hele eller deler av det tidligere livsløpet, for eksempel "livstidsprevalens" for ulike diagnoser. $\mathrm{Vi}$ ville derfor vente at forskjellen mellom gifte/samboende og aldri gifte ville være størst for nåvarende symptomer på dårlig mental helse, mens forskjellen mellom gifte/samboende og tidligere gifte/samboende skulle være størst for "historiske" mål på mental helse (livstidsprevalens).

Ut fra det ovenstående vil vi fremme de følgende hypotesene: 1) Gifte personer har bedre mental helse enn aldri gifte, tidligere gifte og samboende. 2) Forskjellen mellom gifte (eventuelt samboende) og tidligere gifte er større for mål på livstidsprevalens enn mål på nåværende symptombelastning. 3) Forskjellen mellom gifte (eventuelt samboende) og enslige i nåværende symptombelastning kan i stort monn forklares ut fra nåværende forskjeller i økonomiske problemer, sosial integrasjon, vennskap og selvbilde, mens forskjeller i livstidsprevalens ikke kan forklares ved hjelp av slike faktorer. 4) For personer som aldri har vært gift eller samboende samt for tidligere gifte (skilte, separerte) vil det virke gunstig for den mentale helsa å gifte seg eller flytte sammen med en samboer. Den siste hypotesen henvender seg til seleksjonsproblematikken ("er det personer med god mental helse som blir gift og/eller klarer å holde på en partner?”) og må belyses ved hjelp av prospektive data, det vil si at vi trenger mål på vedkommendes symptombelastning før ekteskapet eller samboerskapet kom i stand.

\section{Metode}

\section{Utvalg}

Denne studien baserer seg på data samlet inn ved to tidspunkter i Helseundersøkelsen i Nord-Trøndelag (HUNT). Den første datainnsamlingen foregikk i perioden januar 1984 til februar 1986 (HUNT-1) og den andre i perioden august 1995 til juni 1997 (HUNT-2). Alle voksne nord-trøndere ble innkalt (i HUNT-2 også deltakere i alderen 14-19 år), og det ble foretatt en rekke medisinske undersøkelser: i HUNT-1 måling av blodtrykk, blodsukker, vekt, kroppshøyde, samt en serie etterundersøkelser for risikopersoner, i HUNT-2 også diverse andre variabler, bl.a. ultralyd for osteoporose og hørselsundersøkelser for utvalgte grupper. Alle deltakere måtte fylle ut et spørreskjema før de medisinske undersøkelsene (skjema 1), og i tillegg fikk deltakerne med seg et spørreskjema som ble delt ut etter de medisinske undersøkelsene og returnert i posten (skjema 2).

I denne studien benytter vi data fra deltagerne som var mellom 20 og 70 år ved den andre datainnsamlingen. Deltagerne over 70 blir ekskludert fordi spørreskjemaene til deltakere over 70 år ikke inneholdt alle de spørsmålene om mental helse som blir benyttet $i$ denne studien. 76953 personer i den aktuelle aldersgruppen ble invitert til å delta. 70,4\% av disse var med i helseundersøkelsen og hadde fylt ut spørreskjema 1. $60,8 \%$ av de inviterte hadde også besvart spørreskjema 2. På grunn av det spesielle designet i HUNT-1 (med tilgang til registerdata og spørreskjemadata fra de som møtte til medisinske undersøkelser men ikke returnerte skjema 2 i posten) har det vært mulig å gå nøye inn på frafallet. Resultatene tyder på svært små forskjeller mellom de som møtte til de medisinske undersøkelser og befolkningen for øvrig, og det er også små forskjeller i subjektivt rapporterte plager (oppgitt i skjema 1) hos de som ikke returnerer skjema 2 (Moum, 1994). Det er med andre ord overveiende sannsynlig at de som møtte og fylte ut spørreskjemaer i NordTrøndelagsundersøkelsene er svært representative for befolkningen som helhet, både når det gjelder sosiodemografisk bakgrunn og psykologiske variabler. Det foreligger fullstendig utfylte skjema ( 1 og 2) fra i alt 37418 personer, dvs. $48,6 \%$ av de som ble invitert til å delta. Av disse var 2176 enslige og ikke samboende ved t1, mens 385 var skilt eller separert og ikke samboende ved t1. Det er disse gruppene som blir brukt $\mathrm{i}$ de prospektive analysene. Tabell 1 viser sammensetningen av materialet etter sivilstand på $\mathrm{t} 1 \mathrm{og} \mathrm{t} 2$.

Nord-Trøndelag er ofte betegnet som et "miniNorge". Geografien, bosettingsmønsteret og den demografiske sammensetningen likner på Norge sett under ett. Fylket har ei stor kystlinje og typiske innlandsområder samt tettere bebygde områder. Men det er også trekk som skiller fylket fra resten av landet. Det finnes ingen store byer over 25000 innbyggere, gjennomsnittsinntekten er litt mindre enn gjennomsnittsinntekten i Norge sett under ett, og andelen med høy utdannelse er litt mindre enn landsgjennomsnittet.

\section{Variabler og mål}

\section{Sivilstand}

Opplysninger fra folkeregisteret gir deltakernes sivilstand med følgende kategorier: gift, ugift, skilt, separert og enke/enkemann. Men disse offisielle kategoriene kan som nevnt innledningsvis være problematiske fordi de ikke omfatter samboere. Derfor ble det inkludert et spørsmål i spørreskjema 2 om man bodde sammen med ektefelle eller samboer. 
Tabell 1. Antall deltagere etter sivilstand og kjønn på t1 og t2.

\begin{tabular}{llrrr}
\hline Utvalg & Sivilstand ved t2 & Menn & Kvinner & \multicolumn{1}{c}{ Alle } \\
\hline Alle deltagere ved t2 & Gift & 10700 & 12333 & 23033 \\
& Enslig & 2864 & 1917 & 4781 \\
& Enslig, tidligere gift & 811 & 1612 & 2423 \\
& Samboer & 2595 & 3039 & 5634 \\
& Samboer, tidligere gift & 673 & 874 & 1547 \\
& Totalt & 17643 & 19775 & 37418 \\
Enslige, ikke samboende på t1 & Gift & 352 & 202 & 554 \\
& Enslig & 719 & 307 & 1026 \\
& Enslig, tidligere gift & 9 & 6 & 15 \\
& Samboer & 399 & 164 & 563 \\
& Samboer, tidligere gift & 12 & 6 & 18 \\
& Totalt & 1491 & 685 & 2176 \\
Skilte/separert ikke samboende på t1 1 & Gift & 34 & 17 & 51 \\
& Enslig, tidligere gift & 89 & 144 & 233 \\
& Samboer, tidligere gift & 44 & 57 & 101 \\
& Totalt & 167 & 218 & 385 \\
\hline
\end{tabular}

Folkeregisterets opplysninger og egenrapportert samboerskap ga grunnlag for følgende kategorisering: 1) Gift (offisielt gift som rapporterte å bo med ektefelle), 2) Enslig (offisielt ugift som rapporterte å ikke bo med samboer), 3) Enslig, tidligere gift (offisielt skilte, separerte, enker og enkemann som rapporterte å ikke leve med samboer), 4) Samboer (offisielt ugift som oppgav å leve med samboer), 5) Samboer, tidligere gift (offisielt skilte, separerte, enker og enkemenn som rapporterte å leve med samboer). Tabell 1 viser antall kvinner og menn i de ulike kategoriene ved $\mathrm{t} 2$.

Nåvarende symptomer på angst og depresjon

Som mål på nåværende symptombelastning for angst og depresjon var det i HUNT-2 inkludert 10 spørsmål fra Hopkins Symptom Checklist-25 (SCL-25). Beregninger fra et delutvalg av HUNT-1 som besvarte hele SCL-25 (Tambs \& Moum, 1993) viste en korrelasjon på 0,97 mellom summen av disse spørsmålene og den fullstendige HSCL-25, med andre ord en meget god overensstemmelse. Siden den foreliggende artikkelen tar for seg prosesser som går over tid var det imidlertid ønskelig å finne et mål på nåværende symptombelastning som også kunne beregnes for HUNT-1. Vi valgte derfor å generere en ny skala for symptombelastning basert på 5 spørsmål som var inkludert både i HUNT-1 og HUNT-2 (heretter også kalt "t1" og "t2"). De 10 HSCL-spørsmålene fra HUNT-2 ble brukt som "gullstandarden", dvs. at vi beregnet en sum av de 5 fellesspørsmålene der det enkelte spørsmål var vektet slik at summen ville korrelere høyest mulig med HSCL. Som vekter for de 5 fellesspørsmålene brukte vi de ustandardiserte regresjonskoeffisientene fra en lineær multippel regresjonsanalyse der summen av de 10 HSCL-spørsmålene var den avhengige variabelen. Summen av de vektede fellesspørsmålene - heretter kalt "pseudo-HSCL" - korrelerer 0,69 med summen av de 10 HSCL-spørsmålene (i HUNT-2). De samme vektene ble brukt på begge tidspunkter og den interne konsistensen for indeksene (dvs. "pseudo-HSCL") er identisk for $\mathrm{t} 1 \mathrm{og} \mathrm{t} 2(\mathrm{alfa}=0,83)$. Korrelasjonen mellom pseudo-HSCL på t1 og t2 (dvs. "test-retest-korrelasjonen") er 0,52 .

De fem spørsmålene og svarkategoriene var (med korrelasjonen (fra $\mathrm{t} 1 / \mathrm{t} 2$ ) mellom spørsmålet og vår indeks "pseudo-HSCL" i parentes): (1) Har du i løpet av den siste måned vart plaget av nervøsitet (irritabel, urolig, anspent eller rastløs)? Nesten hele tida, Ofte, Av og til, Aldri ( $\mathrm{r}=0,85 / 0,87)$; (2) Har du i det store og hele en rolig og god følelse inne $i$ deg? Nesten hele tida, Ofte, Av og til, Aldri (r=0,72/0,76); (3) Føler du deg stort sett sterk og opplagt eller trøtt og sliten? Meget sterk og opplagt, Sterk og opplagt, Ganske sterk og opplagt, Både/og, Ganske trøtt og sliten, Trøtt og sliten, Svært trøtt og sliten (r=0,72/0,74); (4) Er du vanligvis glad eller nedstemt? Svært nedstemt, Nedstemt, Nokså nedstemt, Både/og, Nokså glad, Glad, Svært Glad (r=0,66/0,75); (5) Når du tenker på hvordan $d u$ har det for tida, er du stort sett fornøyd med tilvorelsen eller er du stort sett misfornøyd? Svært fornøyd, Meget fornøyd, Ganske fornøyd, Både/og, Nokså misfornøyd, Meget misfornøyd, Svært misfornøyd $(\mathrm{r}=0,68 / 0,72)$.

Skårene på pseudo-HSCL-indeksene ble lineært transformert slik at de varierer mellom 0 og 100 . Høye skårer indikerer stor belastning av symptomer på angst/depresjon. Gjennomsnittsskårene på pseudoHSCL var på t2 (t1) 28,6 (28,7) for kvinner og 25,8 $(25,6)$ for menn. Standardavviket var på $\mathrm{t} 2(\mathrm{t} 1) \quad 16,2$ $(16,0)$ for kvinner og 15,4 $(14,9)$ for menn.

\section{Livstidsprevalens for alvorlig depresjon}

En serie spørsmål som skulle beregne livstidsprevalensen for alvorlig depresjon ("major depression") var inkludert i spørreskjema 2 ved $\mathrm{t} 2$, men ikke ved $\mathrm{t} 1$. Vi benyttet den samme metoden som Kendler et al. 
(1993) brukte. Deltagerne ble spurt om livstidsforekomst av fem viktige depressive symptomer som var valgt ut blant de ni diagnosekriteriene på en alvorlig depresjon i DSM-III-R. Disse fem var 1) deprimert, trist og nedfor, 2) endringer $i$ appetitten, 3) plaget av kraftløshet eller mangel på overskudd, 4) bebreidet seg selv og følt seg verdiløs, 5) hatt problemer med å konsentrere seg eller vanskelig for à ta beslutninger. Deretter ble deltakerne spurt om minst tre av disse symptomene noen gang hadde opptrådt samtidig i minst to uker. De som svarte positivt på dette siste spørsmålet og som samtidig oppgav at "deprimert, trist og nedfor" var ett av symptomene ble klassifisert som "tilfelle" (case) for minst én episode med alvorlig depresjon $\mathrm{i}$ løpet av livet.

\section{Alder}

Alder ved datainnsamlingstidspunktet er basert på opplysninger fra Folkeregisteret. I de følgende analysene blir alder brukt som en variabel med 5 kategorier: 1) 20 til 29 år, 2) 30 til 39 år, 3) 40 til 49 år, 4) 50 til 59 år og 5) 60 til 69 år.

\section{Utdanning}

Utdanning var selvrapportert etter følgende kategorier: 1) Grunnskole 7-10 år, framhaldsskole eller folkehøgskole, 2) Realskole, middelskole, yrkesskole eller etttil toårig videregående skole, 3) Artium, økonomisk gymnas eller allmennfaglig retning i videregående skole, 4) Høgskole/universitet, mindre enn 4 år og 5) Høgskole/universitet, 4 år eller mer.

\section{Venner}

Et spørsmål om venner med ordlyden "Føler du at du har mange nok gode venner"? var inkludert. Svarkategoriene var"ja" og "nei".

\section{Økonomiske vansker}

Økonomiske vansker ble det spurt etter på følgende måte: "Har det i løpet av det siste året hendt at husholdningen har hatt vansker med å klare de løpende utgifter til mat, transport, bolig og liknende." Svaralternativene var 1) "ja, ofte", 2) "ja, av og til", 3) "ja, en sjelden gang", 4) "nei, aldri".

\section{Selvbilde}

Rosenbergs 10-ledds skala som måler generell selvaksept (Rosenberg, 1965) ble kortet ned til 4 ledd ved hjelp av et eksisterende datamateriale (Ystgaard, 1993). Det kunne vises at summen av disse leddene korrelerer 0,95 med originalskalaen. Alfa-reliabiliteten for kortversjonen ble $\mathrm{i}$ dette materialet estimert til 0,80 . Kortversjonen, som inngår i Skjema 2 fra HUNT-2 omfatter følgende ledd: 1) "Jeg har en positiv holdning til meg selv", 2) "Jeg føler meg virkelig ubrukelig til tider", 3) "Jeg føler at jeg ikke har mye å være stolt av", 4) "Jeg føler at jeg er en verdifull person, i alle fall på lik linje med andre". Svarkategoriene var: "svært enig", "enig", "uenig", "svært uenig". Spørsmål 2 og 3 er snudd før summeringen slik at en høy skåre indikerer godt selvbilde. Alfa-reliabiliteten for denne indeksen er i vårt materiale 0,71 .

\section{Opplevd tilhørighet i lokalsamfunnet}

Tolv spørsmål fra Tom Sørensens skjema for vurdering av sosiokulturell integrasjon i et lokalsamfunn var inkludert i spørreskjema 2 (Sørensen et al., 2000). Teoretisk er dette instrumentet forankret i Aleksander Leightons arbeider (Leighton, 1959; Hughes et al., 1960; Leighton et al., 1963).

Utsagnene var: 1) "Jeg føler et sterkt fellesskap med de som bor her", 2) "Selv om noen tar initiativ, er det ingen som blir med på det som settes i gang her", 3) "Hvis jeg flytter herfra, vil jeg lengte tilbake", 4) "Man kan ikke stole på hverandre her", 5) "Når noe skal gjøres her, er det lett å få folk med”, 6) "Det er vanskelig å få kontakt med folk her", 7) "Det er godt samhold her", 8) "Ingen orker å ta initiativ til noe lenger her", 9) "Folk trives godt her", 10) "Folk her kan ha store problemer uten at naboen vet noe", 11) "Det er alltid noen som tar initiativ til å løse nødvendige oppgaver her", 12) "Folk snakker lite med hverandre her". Svaralternativene var: 1) "helt enig", 2) "delvis enig", 3) "usikker", 4) "delvis uenig", 5) "helt uenig". En enkel additiv indeks (basert på vektene 1-5 som i det foregående), der halvparten av spørsmålene blir snudd slik at en høy sumskåre indikerer sterk tilhørighet, gir en alfa-reliabilitet på 0,81 .

\section{Statistiske analyser}

Alle analyser har blitt utført med SPSS 10. Signifikansnivået har blitt satt til 0,01 , bortsett fra i de longitudinelle analysene som også oppgir funn som er signifikante på 0,05-nivået fordi de gruppene som blir benyttet $\mathrm{i}$ disse analysene er relativt små. Til kovariansanalyser/multiple regresjoner anvendes programmet "General Linear Model".

\section{Resultater}

Rapporterer gifte personer bedre mental helse enn samboere, enslige og tidligere gifte? Tabell 2 viser at både gifte menn og kvinner oppgir bedre mental helse målt $\mathrm{i}$ form av symptomer på angst og depresjon enn enslige og tidligere gifte, mens symptomnivået er litt (men ikke signifikant) lavere hos samboende (Tabell 2, kolonne 2). Det samme mønsteret finner for livstidsprevalens på alvorlig depresjon (Tabell 3 , kolonne 2).

Forskjellen mellom gifte (eventuelt samboende) og tidligere gifte er spesielt stor for målet på livstidsprevalens på alvorlig depresjon slik som vi påsto i vår hypotese nr. 2 ovenfor: Mens den nåværende symptombelastningen er omtrent den samme hos enslige (dvs. aldri gifte) og samboere som er tidligere gift (Tabell 2), er odds for å ha opplevd en episode med alvorlig depresjon nesten tre ganger større hos samboende tidligere gifte menn, og omtrent to ganger større hos samboende, tidligere gifte kvinner (Tabell 3). 
Tabell 2. Gjennomsnittlige skårer på "pseudo-HSCL" (nåværende symptomer på angst/depresjon) ved t2 uten og med kontroll for mulige mellomliggende variabler. Signifikante resultater for variablene "sivilstand" og signifikante gjennomsnittlige avvik $(p<0,01)$ fra gruppa "gift" merket med *. Kovariansanalyse med sivilstand som faktor og øvrige uavhengige variabler som kovariater.

\begin{tabular}{lllll}
\hline \multicolumn{1}{c}{ Sivilstand } & \multicolumn{1}{c}{1} & \multicolumn{1}{c}{2} & \multicolumn{1}{c}{3} \\
\hline Menn & Gift & 25,08 & 24,85 & 25,48 \\
& Enslig & $26,21^{*}$ & $26,74^{*}$ & 25,93 \\
& Enslig, tidligere gift & $31,14^{*}$ & $30,71^{*}$ & $27,41^{*}$ \\
& Samboer & 24,34 & 24,90 & 24,72 \\
& Samboer, tidligere gift & $26,99^{*}$ & $26,72^{*}$ & 24,78 \\
& F-verdier & $35,37^{*}$ & $33,98^{*}$ & $7,70^{*}$ \\
& & & \\
Kvinner & Gift & 28,04 & 27,87 & 28,51 \\
& Enslig & 28,94 & $29,61^{*}$ & 28,26 \\
& Enslig, tidligere gift & $32,23^{*}$ & $31,73^{*}$ & 29,21 \\
& Samboer & $26,57^{*}$ & 27,17 & $27,19^{*}$ \\
& Samboer, tidligere gift & $31,45^{*}$ & $31,16^{*}$ & 29,69 \\
& F-verdier & $42,18^{*}$ & $33,05^{*}$ & $7,33^{*}$ \\
\hline
\end{tabular}

1: Ukontrollert

2: Kontrollert lineært for alder og utdanning

3: Kontrollert lineært for alder, utdanning, nok venner, nærmiljø, økonomiske vansker og selvbilde

Tabell 3. Livstidsprevalens for alvorlig depresjon etter sivilstand og kjønn ved t2. Odds ratio relativt til gifte, uten og med kontroll for mulige mellomliggende variabler. Multiple logistiske regresjonsanalyser.

\begin{tabular}{llccc}
\hline & & 1 & 2 & 3 \\
\hline Menn & Gift & - & - & - \\
& Enslig & $1,27^{*}$ & $1,28^{*}$ & 1,12 \\
& Enslig, tidligere gift & $3,93^{*}$ & $3,97^{*}$ & $3,10^{*}$ \\
& Samboer & 0,98 & 0,99 & 0,92 \\
& Samboer, tidligere gift & $3,21^{*}$ & $3,25^{*}$ & $2,83^{*}$ \\
& Wald & $453,5^{*}$ & $454,1^{*}$ & $281,4^{*}$ \\
& & & \\
Kvinner & Gift & - & - & - \\
& Enslig & $1,38^{*}$ & $1,37^{*}$ & $1,21^{*}$ \\
& Enslig, tidligere gift & $3,12^{*}$ & $3,13^{*}$ & $2,64^{*}$ \\
& Samboer & $0,71^{*}$ & $0,71^{*}$ & $0,67^{*}$ \\
& Samboer, tidligere gift & $2,57^{*}$ & $2,59^{*}$ & $2,39^{*}$ \\
& Wald & $707,18^{*}$ & $670,62^{*}$ & $469,10^{*}$ \\
\hline
\end{tabular}

$* \mathrm{p} \leq 0,01$

1: Ukontrollert

2: Kontrollert lineært for alder og utdanning

3: Kontrollert lineært for alder, utdanning, nok venner, nærmiljø, økonomiske vansker og selvbilde

Her må det innskytes at sammenlikninger på tvers av våre mål på mental helse kan synes noe problematisk: livstidsprevalens for alvorlig depresjon er målt med en kategorisk variabel og analysert i logistiske regresjonsanalyser, mens "pseudo-HSCL" er en kontinuerlig variabel analysert med minste kvadraters metode (variansanalyse/regresjonsanalyse). Kan slike resultater egentlig sammenliknes? For å sjekke dette ble
"pseudo-HSCL" omgjort til en kategorisk variabel (med kuttpunkt på den 80. persentilen) og lagt inn i som en avhengig variabel i logistiske regresjonsanalyser. Resultatene, som ikke er vist i denne artikkelen, ga resultater som substansielt sett er helt parallelle med de som er oppgitt i Tabell 2.

Den tredje hypotesen var at effekten av sivilstand på mental helse helt eller delvis går gjennom de tidligere nevnte sosiale, økonomiske og psykologiske variablene (nok venner, sosial integrasjon, økonomiske vansker, selvbilde). For at disse antatt mellomliggende variablene skal kunne betraktes som forklaringsmekanismer må de være sterkt korrelert både med den uavhengige variabelen (her: sivilstand) og med den avhengige variabelen (her: mental helse). Hypotesen om at vi har funnet et sett med mellomliggende variabler styrkes dersom den statistiske sammenhengen mellom den uavhengige variabelen (sivilstand) og den avhengige variabelen (mental helse) forsvinner - eller i det minste svekkes betraktelig - når vi kontrollerer for de mellomliggende variablene (Baron \& Kenny, 1986).

Som allerede vist i Tabell 2 og Tabell 3 (andre kolonne i begge) kunne sivilstand predikere de avhengige variablene kontrollert for alder og utdanning. Analyser som ikke blir gjengitt $\mathrm{i}$ detalj her viste at sivilstand (kontrollert for alder og utdanning), henger sammen med de mellomliggende variablene på samme måte som for mental helse, dvs. bedre selvbilde, flere venner, større nærmiljøintegrasjon og færre økonomiske vansker blant gifte enn blant enslige. Tilsvarende fant vi en sterk sammenheng mellom de mellomliggende variablene og nåværende symptomer på angst og depresjon samt livstidsforekomsten på depresjon, etter at vi hadde kontrollert for alder og utdanning.

Etter at forutsetningene for å teste ut de mellomliggende variablene var tilfredsstilt, undersøkte vi om effekten av sivilstand på de avhengige variablene forsvant eller ble redusert når vi kontrollerte for de mellomliggende variablene. I tabellene gjengis bare resultatene som viser virkningen av at det ble kontrollert for hele settet av mellomliggende variabler. Men for at den relative betydningen av hver enkelt av de antatte mellomliggende variablene skulle kunne vurderes, ble det $\mathrm{i}$ andre analyser også kontrollert for hele settet av de mellomliggende variabler minus én av de mellomliggende variablene. Resultatene fra disse analysene blir ikke vist her, men refereres summarisk i teksten når de er av betydning (kan fås ved henvendelse til forfatterne). Som vist i Tabell 4 var ikke den innbyrdes sammenhengen mellom de mellomliggende variablene så sterk at det er problematisk å beregne effekten av enkeltvariabler. I Tabell 2 (kolonne 3) kan vi se at effekten av sivilstand på nåværende symptomer på angst og depresjon blir meget betydelig redusert når vi kontrollerer for de mellomliggende variablene. Men vi finner ikke et tilsvarende mønster når livstidsprevalensen for alvorlig depresjon er den avhengige variabelen (Tabell 3). Disse resultatene er i overensstemmelse 
med vår hypotese $\mathrm{nr} .3$, nemlig at forskjellene mellom sivilstandsgrupper i nåvaerende symptombelastninger i stort monn er en funksjon av de fire mellomliggende variablene, mens vi ikke kan gjøre rede for forskjeller i tidligere mental helse på den samme måten.

Vår fjerde hypotese gjaldt den antatte positive effekten av å gifte seg eller flytte sammen med en partner. Her tillater datamaterialet oss å følge opp en gruppe enslige, ikke tidligere gifte personer prospektivt. Som vi kan se i Tabell 5 hadde både kvinner og menn som har giftet seg bedre mental helse enn de som fortsatt er enslige og personer som er "enslig, tidligere gift". I tredje kolonne i Tabell 5 ser vi at forskjellen mellom disse gruppene fortsatt er signifikant når vi kontrollerer for nivået av angst og depresjon ved t1 med unntak av forskjellen mellom gifte og enslige menn som forsvinner. Som vi kan se i Tabell 5 (kolonne fire) er forskjellen i nåværende angst- og depresjonssymptomer mellom de kvinnene som har giftet seg og de som fortsatt er enslige mediert gjennom de mellomliggende variablene. Forskjellen vi fant mellom menn som hadde giftet seg og menn som var "enslige, tidligere gifte" går også gjennom hele settet av mellomliggende variablene. Men forskjellen i nåværende angst- og depresjonssymptomer mellom kvinnene som har giftet seg og de som har blitt "enslige, tidligere gifte" viser seg hovedsakelig å skyldes "bomiljø", "økonomiske vansker" og "dårlig selvbilde".

Interessant nok finner vi også at kvinner som har blitt samboere $\mathrm{i}$ tiden mellom $\mathrm{t} 1$ og $\mathrm{t} 2$ oppgir mer symptomer på angst og depresjon enn de som har giftet seg. Denne forskjellen holder seg også når vi kontrollerer for utgangsnivået av angst og depresjon, men reduseres når vi kontrollerer for de mellomliggende variablene.

Hvilke endringer i mental helse finner vi hos de som var skilt eller separert og ikke hadde samboer på t1 og som har endret sivilstand fra t1 til t2? Hypotesen var at personer som har giftet seg på nytt ville ha bedre mental helse enn de som fortsatt var enslige. Som vi ser av Tabell 6 er symptomnivået gjennomgående høyere hos enslige enn hos gifte og samboende, men forskjellene her er ikke signifikante. Det må tilføyes at det relativt beskjedne antallet personer i Tabell 6 gjør at vi ikke har svært stor statistisk styrke til å oppdage forskjeller.

Tabell 4. Korrelasjoner (Pearsons) mellom de mellomliggende variablene. Alle korrelasjoner signifikante med $\mathrm{p}<0,01$.

\begin{tabular}{llccc}
\hline \multirow{4}{*}{ Menn } & & Nok venner & Nærmiljø & Selvbilde \\
& Nok venner & & & \\
& Nærmiljø & $-0,27$ & & \\
& Selvbilde & $-0,18$ & 0,20 & \\
& Øk. vansker & $-0,10$ & 0,16 & 0,14 \\
& & & & \\
Kvinner & Nok venner & & & \\
& Nærmiljø & $-0,30$ & & \\
& Selvbilde & $-0,22$ & 0,23 & 0,15 \\
\hline & Øk. vansker & $-0,12$ & 0,16 & \\
\hline
\end{tabular}

Tabell 5. Gjennomsnittlige skårer på "pseudo-HSCL" (nåværende symptomer på angst/depresjon) ved t 2 samt endring fra t 1 til t 2 uten og med kontroll for mulige mellomliggende variabler. Kovariansanalyse med sivilstand som faktor og øvrige uavhengige variabler som kovariater. Signifikans for variabelen "sivilstand ved t2" og signifikante gjennomsnittlige avvik fra gruppa "gift" merket med * og **. Bare for deltakere som var enslige ved $\mathrm{t} 1$.

\begin{tabular}{|c|c|c|c|c|c|}
\hline & Sivilstand ved t2 & 1 & 2 & 3 & 4 \\
\hline \multirow[t]{6}{*}{ Menn } & Gift & 24,53 & 24,48 & 25,54 & 26,30 \\
\hline & Enslig & $27,37 * *$ & $27,44^{*}$ & 26,92 & 26,15 \\
\hline & Enslig, tidligere gift & $38,61^{* *}$ & $38,52^{*}$ & $36,45^{*}$ & 31,25 \\
\hline & Samboer & 24,53 & 24,46 & 24,60 & 25,49 \\
\hline & Samboer, tidligere gift & 29,53 & 29,37 & 26,12 & 24,24 \\
\hline & F-verdier & $4,44 * *$ & $4,14 * *$ & $2,93 *$ & 0,76 \\
\hline \multirow[t]{6}{*}{ Kvinner } & Gift & 24,97 & 24,30 & 26,05 & 27,20 \\
\hline & Enslig & $29,85^{* *}$ & $30,67 * *$ & $29,43 *$ & 28,85 \\
\hline & Enslig, tidligere gift & $39,01 *$ & $37,95^{*}$ & $39,07 *$ & 37,34 \\
\hline & Samboer & $29,98 * *$ & $29,34 * *$ & $29,49 *$ & 29,18 \\
\hline & Samboer, tidligere gift & 28,28 & 27,48 & 26,72 & 27,76 \\
\hline & F-verdier & $3,87 * *$ & $4,50 * *$ & $2,69 *$ & 1,38 \\
\hline \multicolumn{6}{|l|}{$* \quad p \leq 0,05$} \\
\hline \multicolumn{6}{|c|}{$* * \mathrm{p} \leq 0,01$} \\
\hline \multicolumn{6}{|c|}{$\begin{array}{l}\text { 1: Ukontrollert } \\
\text { 2: Kontrollert lineært for alder og utdanning } \\
\text { 3: Kontrollert lineært for alder og utdanning og HSCL-1 }\end{array}$} \\
\hline
\end{tabular}


Tabell 6. Gjennomsnittlige skårer på "pseudo-HSCL" (nåværende symptomer på angst/depresjon) ved $\mathrm{t} 2$ samt endring fra t 1 til t 2 uten og med kontroll for mulige mellomliggende variabler. Kovariansanalyse med sivilstand som faktor og øvrige uavhengige variabler som kovariater. Signifikans for variabelen "sivilstand ved t2" og signifikante gjennomsnittlige avvik fra gruppa "gift" merket med * og **. Bare for deltakere som var skilt eller separert og ikke samboende ved $t$.

\begin{tabular}{llrrrr}
\hline & Sivilstand ved t2 & \multicolumn{1}{c}{1} & \multicolumn{1}{c}{2} & \multicolumn{1}{c}{3} & \multicolumn{1}{c}{4} \\
\hline \multirow{2}{*}{ Menn } & Gift & 23,45 & 23,29 & 23,71 & 24,96 \\
& Enslig, tidl. gift & 28,20 & 28,30 & 27,45 & 26,78 \\
& Samboer, tidl. gift & 24,12 & 24,04 & 25,44 & 25,83 \\
& F-verdier & 1,77 & 1,78 & 1,12 & 0,32 \\
& & & & \\
Kvinner & Gift & 23,51 & 23,30 & 27,07 & 29,00 \\
& Enslig, tidl. gift & 32,26 & 32,51 & 31,64 & 31,02 \\
& Samboer, tidl. gift & 31,18 & 30,61 & 31,68 & 32,67 \\
& F-verdier & 1,87 & 1,95 & 0,67 & 0,56 \\
\hline
\end{tabular}

1: Ukontrollert

2: Kontrollert lineært for alder og utdanning

3: Kontrollert lineært for alder og utdanning og HSCL-1

4: Kontrollert lineært for alder, utdanning, HSCL-1, nok venner, nærmiljø, økonomiske vansker og selvbilde

\section{DISKUSJON}

Våre resultater viser at gifte og samboende menn og kvinner rapporterer bedre mental helse enn enslige og bedre mental helse enn tidligere gifte som på t 2 enten er enslige eller samboende. Dette gjelder både nåværende symptomer på angst og depresjon og livstidsprevalensen på alvorlig depresjon. Den relative fordelen som gifte og samboende har når det gjelder nåværende symptomer på angst og depresjon viser seg å være mediert gjennom et godt selvbilde, opplevelsen av å ha nok venner, bedre lokalsamfunnsintegrasjon og mindre økonomiske vansker. Men mønsteret med at færre gifte kvinner og menn har opplevd en alvorlig depresjon enn andre sivilstandsgrupper (med unntak av samboende) lar seg ikke forklare av slike antatte medierende variabler. Siden episoden(e) med alvorlig depresjon kan ha opptrådt for mange år siden er det heller ikke rimelig å forvente at deltakernes nåværende sosiale eller økonomiske situasjon skal kunne brukes som forklaringsfaktorer.

I tråd med vår hypotese nummer to viste det seg at forskjellen mellom gifte og tidligere gifte er spesielt stor for målet på livstidsprevalensen av alvorlig depresjon. Dette kan støtte Umberson \& Williams' (1999) antakelse om at det primært er forhold rundt selve oppløsningen av parforholdet som gjør at tidligere gifte har dårligere mental helse. Men fordi spørsmålene som inngår i "pseudo-HSCL" ikke er helt de samme som inngår i livstidsprevalensen på alvorlig depresjon vil vi være litt forsiktige med en slik konklusjon. Det er mulig at oppløsning av ekteskap/samboerskap er nærmere knyttet til depresjon enn til generelt "distress", og at forskjellen mellom de to målene ikke bare skyldes de forskjellige måleperiodene.
Samboende menn og kvinner rapporterer ikke dårligere mental helse enn gifte på noen av våre mål. Tvert i mot finner vi at samboende kvinner i mindre grad enn gifte har opplevd en alvorlig depresjon. At de samboende som ikke har vært gift tidligere ikke har dårligere mental helse enn gifte støtter opp om Ross' (1995) konklusjon om at det er tilknytningen til en betydningsfull person i seg selv og ikke ekteskapet som bidrar til god mental helse. Mønstret med lavere livstidsprevalens for alvorlig depresjon hos samboende enn hos gifte kvinner er så vidt vi vet ikke observert tidligere og bør undersøkes nærmere.

Når vi følger opp personer som ved t 1 var "enslige og ikke samboende" finner vi støtte for hypotesen at de som har blitt gift har færre symptomer på angst og depresjon enn de som fortsatt er enslige. Dette gjelder både menn og kvinner. Når vi kontrollerer for nivået av angst og depresjon ved t1 (dvs. ser på endring $\mathrm{i}$ symptomnivået) er denne forskjellen fortsatt signifikant for kvinnenes del men ikke for mennene, selv om tendensen er den samme (dvs. mest symptomer hos "enslige" og "enslige, tidligere gifte"). Det kan med andre ord se ut som ekteskapet (og samboerskapet) er noe mer beskyttende for kvinner.

Endringen i mental helse hos de kvinnene som har blitt gift sammenlignet med de som har forblitt enslige går først og fremst gjennom bedre opplevd ncermiljø, ferre økonomiske vansker og bedre selvbilde. Resultatene tyder på at de kvinnene som gifter seg opplever å bli bedre integrert i sitt nærmiljø, at de får bedre økonomi gjennom en felles husholdning, og at det er gunstig for selvbildet å bli gift. For menn er det først og fremst et bedre selvbilde som skiller mellom de som er blitt gift og de som fremdeles er enslige. Vi skal selvsagt være forsiktige med å trekke alt for bastante konklusjoner da målene på de medierende faktorene kun er fra t2. Vi vet med andre ord ikke sikkert om endring i sivilstand førte til endring i de medierende faktorene for så å gi endring i mental helse.

Interessant nok finner vi at kvinner som har blitt samboere i tiden mellom $\mathrm{t} 1$ og t 2 har mer symptomer på angst og depresjon enn de som hadde giftet seg. Denne forskjellen holdt seg også når vi kontrollerer for utgangsnivået av angst og depresjon, men forsvinner når vi kontrollerer for de mellomliggende variablene. Resultatene kan tyde på at det - blant de som var enslige ved $\mathrm{t} 1$ - er en viss seleksjon av kvinner med dårligere mental helse inn $i$ gruppa av samboere, $i$ alle fall sammenliknet med de som har giftet seg mellom t1 og t2. Dårligst mental helse ved t2 finner vi imidlertid blant enslige tidligere gifte kvinner, dvs. blant de som siden $\mathrm{t} 1$ har rukket både å gifte seg og skille seg (eller bli enker). Dette holder også når vi tar hensyn til deres mentale helse ved t1.

Hypotesen om at gjengifte (eller det å flytte sammen med en samboer) for de som var skilt/separert ved t1 ville føre til bedre mental helse finner ikke sterk støtte $\mathrm{i}$ vårt materiale $\mathrm{i}$ form av signifikante resultater. Men tendensen i materialet er likevel at de som har 
giftet seg på nytt har et lavere nivå av symptomer på angst og depresjon (samt en mer fordelaktig endring fra t1 til t2) enn de som fortsatt lever alene.

Oppsummerende kan vi konkludere med at:

(1) Både blant menn og kvinner rapporterer gifte og samboende farre symptomer på angst og depresjon, samt farre episoder med alvorlige depresjon $i$ løpet av livet enn enslige og tidligere gifte.

(2) Den gunstigere situasjonen blant gifte og samboende når det gjelder nåvcerende symptomer på angst og depresjon kan i stor grad knyttes til slike mellomliggende variabler som (a) en bedre økonomisk situasjon, (b) en opplevelse av å ha nok venner, (c) en bedre integrasjon i lokalsamfunnet, og (d) et bedre selvbilde. For menn er det særlig selvbildet som er utslagsgivende, mens det for kvinner er økonomiske vansker som i størst grad gir økte symptomer hos enslige og tidligere gifte (sammenlignet med gifte og samboende).
(3) Den lavere forekomsten episoder med alvorlig depresjon tidligere i livet kan ikke knyttes til de nevnte mellomliggende variablene, men kan muligens skyldes forhold rundt (a) selve oppløsningen av tidligere ekteskap/samboerskap, eller (b) tidligere livspåkjenninger knyttet til tilværelsen som enslig.

(4) Hypotesen om at det å finne seg en partner påvirker menns og kvinners mentale helse blir støttet av at nivået på symptomer på angst og depresjon (rapportert på undersøkelsestidspunktet) over en 10-års periode endrer seg i gunstig retning blant de som forandrer status fra enslig til gift/samboende. Gjengifte eller det å finne seg en samboer gir ikke så store utslag på endring symptombelastningen blant de kvinner og menn som allerede ved første måling hadde et oppløst ekteskap bak seg, men tendensen er at vi finner den laveste symptombelastningen og den mest gunstige utviklingen i symptomer hos kvinner og menn som har giftet seg på nytt.

\section{REFERANSER}

Baron RM, Kenny DA (1986). The moderator/mediator variable distinction in social psychological research: Conceptual, strategic and statistical considerations. J Pers Soc Psychol, 51, 1173-1182.

Booth A, Amato PR (1991). Divorce and psychological stress. J Health Soc Behav, 32, 396-407.

Demo DH, Acock AC (1996). Singlehood, marriage, and remarriage: The effects of family structure and family relationships on mothers' well-being. J Fam Issues, 17, 388-407.

Gove WR, Shin H-C (1989). The psychological well-being of divorced and widowed men and women. J Fam Issues, 10, 122-144.

Horwitz AV, White HR (1991). Becoming married, depression, and alcohol problems among young adults. $J$ Health Soc Behav, 32, 221-237.

Horwitz AV, White HR, Howell-White S (1996). Becoming married and mental health. J Marriage Fam, 58, 895907.

Hughes CC, Tremblay MA, Rappaport RN, Leighton AH (1960). People of Cove and Woodflot. Communities from the viewpoint of social psychiatry. New York: Basic Books.

Kendler KS, Neale MC, Kessler RC, Heath AC, Eaves LJ (1993). The lifetime history of major depression in women: Reliability of diagnosis and heritability. Arch Gen Psychiatry, 50, 863-870.

Kessler RC (1982). A disaggregation of the relationship between socioeconomic status and psychological distress. Am Sociol Rev, 47, 752-764.

Leighton AH (1959). My name is Legion. New York: Basic Books.

Leighton DC, Harding IS, Maclin DB, Mackmillan AM, Leighton AH (1963). The character of danger. Psychiatric symptoms in selected communities. The Stirling County study of psychiatric disorder and sociocultural environment, Vol III. New York: Basic Books.

Mastekaasa A (1994). The subjective well-being of the previously married: The importance of unmarried cohabitation and time since widowhood or divorce. Social Forces, 73, 665-692.

Menaghan EG, Lieberman MA (1986). Changes in depression following divorce: A panel study. J Marriage Fam, 48, 319-328.

Moum T (1994). Is subjective well-being a predictor of nonresponse in broad population surveys? Soc Indicator Res, 32, 1-20.

Newcomb MD (1987). Cohabitation and marriage: A quest for independence and relatedness. Appl Soc Psychol Аппи, 7, 128-156.

Pearlin LI, Johnson JS (1977). Marital status, life strain, and depression. Am Sociol Rev, 42, 704-715.

Rosenberg M (1965). Society and the adolescent self-image. New Jersey: Princeton University Press.

Ross CE (1995). Reconceptualizing marital status as continuum of social attachment. J Marriage Fam, 57, 129140.

Ross CE, Huber J (1985). Hardship and depression. J Health Soc Behav, 26, 312-327. 
Ross CE, Mirowsky J, Goldsteen K (1990). The impact of family on health: The decade in review. J Marriage Fam, 52, 1059-1078.

Shapiro A (1996). Explaining psychological distress in a sample of remarried and divorced couples: The influence of economic distress. J Fam Issues, 17, 186-203.

Spanier GB, Furstenberg FF, Jr (1982). Remarriage and divorce: a longitudinal analysis of well-being. J Marriage Fam, 44, 709-720.

Sørensen T, Kleiner R, Mastekaasa A, Sandanger I, Moum T, Bøe N, Klepp O (2001). North-Coast series in community psychiatry. Number 01-02.

Sørensen T, Mastekaasa A, Sandanger I, Kleiner R, Moum T, Klepp O, Bøe N (2002). Contribution of local community integration and personal social network support to mental health. Norsk Epidemiologi, 12, 269-274.

Sørensen T, Kleiner R, Bøe N, Moum T, Sandanger I (2000). Sociocultural integration \& disintegration. The local-community approach to mental health. North-Coast series in community psychiatry. Number 01-01.

Tambs K, Moum T (1993). How well can a few questionnaire items indicate anxiety and depression? Acta Psychiatr Scand, 87, 364-367.

Umberson D, Williams K (1990). Family status and mental health. In: Aneshensel CS, Phelan JC, eds. Handbook of the Sociology of Mental Health. New York: Kluwer Academic/Plenum Publishers: 225-253.

Umberson D, Wortman CB, Kessler RC (1992). Widowhood and depression: Explaining long-term gender differences in vulnerability. J Health Soc Behav, 33, 10-24.

Weingarten HR (1985). Marital status and well-being: A national study comparing first-married, currently divorced, and remarried adults. J Marriage Fam, 47, 653-662.

Williams DR, Takeuchi DT, Adair RK (1992). Marital status and psychiatric disorders among blacks and whites. J Health Soc Behav, 33, 140-157.

Ystgaard M (1993). Sårbar ungdom og sosial støtte. En tilnærming til forebygging av psykisk stress og selvmord. Rapport 93, Oslo: Senter for sosialt nettverk og helse.

Zick CD, Smith KR (1991). Marital transitions, poverty, and gender differences in mortality. J Marriage Fam, 53, 327-336. 